\title{
E-textbook technology: Are instructors using it and what is the impact on student learning?
}

E-textbook technology

\author{
Kim Roberts \\ Athens State University, Athens, Alabama, USA and \\ The University of Alabama, Tuscaloosa, Alabama, USA, and \\ Angela Benson and Jamie Mills \\ The University of Alabama, Tuscaloosa, Alabama, USA
}

\begin{abstract}
Purpose - Today's digital and mobile learning environment has contributed to the increased availability of and interest in e-textbooks, and many school systems are conducting trials to evaluate their effectiveness. The purpose of this paper is to identify and analyze instructors' levels of use (LoU) of e-textbook features and innovations at a southeastern US community college. This study also evaluated the effectiveness of e-textbooks compared to paper textbooks on student achievement during a pilot period of e-textbook implementation.

Design/methodology/approach - Using a survey research design, the LoU of the Innovation framework was applied to identify and analyze instructors' LoU rankings for eight e-textbook features. The study also used historical data on student demographics and final course grades to evaluate student achievement between text formats. Descriptive and inferential statistics were used to answer the research questions.

Findings - Results showed that e-textbook features were used at a low to non-existent level by instructors and that there was no significant difference in grade average between text formats among students. However, interactions between text format, age and gender were found.

Originality/value - This study added to the body of knowledge regarding e-textbook efficacy. While many studies stop with the conclusion that there is no difference in student outcomes between text formats, this study addressed a gap in literature on how to improve student performance with e-textbook technology by using the LoU of an innovation framework.
\end{abstract}

Keywords Electronic textbooks, Student achievement, Levels of use

Paper type Research paper

\section{Introduction}

Textbooks have a long association with classrooms in the USA (Wakefield, 2006). Whether the text plays a primary role in class discourse or a supplementary role as a guide or reference, the textbook is considered an essential learning tool in physical and virtual classrooms across the nation (Rockinson-Szapkiw et al., 2013).

While the purpose of the textbook remains unchanged, its delivery method has changed to support the digital and mobile environment of the 21st century. According to Smith and Caruso (2010), 80\% of college and university students own laptops. In addition, college students are using tablets, smartphones and e-book readers and now expect access to academic resources on these devices. With the growth in mobile device ownership, the market is now seeing an increase in the number of e-textbook providers and e-textbook availability (Miller et al., 2013). E-textbooks are advancing from mere portable document format (PDF)

(C) Kim Roberts, Angela Benson and Jamie Mills. Published in Journal of Research in Innovative Teaching \& Learning. Published by Emerald Publishing Limited. This article is published under the Creative CommonsAttribution (CC BY 4.0) licence. Anyone may reproduce, distribute, translate and create derivative worksof this article (for both commercial and non-commercial purposes), subject to full attribution to theoriginal publication and authors. The full terms of this licence may be seen at http:// creativecommons.org/licences/by/4.0/legalcode

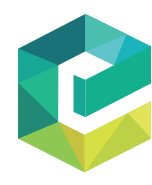

Journal of Research in Innovative Teaching \& Learning Vol. 14 No. 3,2021 Emerald Publishing Limited DOI 10.1108/JRIT-04-2021-0028 
JRIT

14,3

versions of hard-copy books to interactive multimedia tools. The definition of an e-textbook has varied and continues to evolve given the rapidly changing devices on which they are offered and the dynamic technologies and features which they offer (Vassiliou and Rowley, 2008). Rockinson-Szapkiw et al. (2013) define e-textbooks as digital books used for formal study and accessed via an electronic device.

While e-textbooks have potential advantages over traditional print textbooks in the areas of cost, student engagement, reading comprehension and mobile learning, research is needed to know more about how e-textbooks are used in classrooms. E-textbooks offer features that can lead to increased interaction between students and the learning content and between students and instructors. However, these potential benefits may not be realized unless instructors take the lead in incorporating the use of e-textbook features in their teaching. Therefore, a study was conducted to identify and analyze instructors' levels of use (LoU) of e-textbook features and innovations at a community college in a southeastern state; to determine if there were differences in instructor LoU profiles across programs of study; and to determine what demographic characteristics of instructors were related to LoU. This study also evaluated the effectiveness of e-textbooks compared to paper textbooks on student achievement during a pilot period of e-textbook implementation. Moreover, the influence of text format on student achievement by age and gender was examined.

The research questions for this study included: (1) What are the instructors' LoU with e-textbook features? (2) Is there a difference in instructors' e-textbook LoU profile ranking across programs of study? (3) What demographic characteristics of instructors (age, gender, rank, years of college-level teaching and number of e-textbook professional development experiences) are related to LoU of e-textbook features? (4) Is there a difference in student achievement level, as measured by the final course average, for students using e-textbooks compared to paper textbooks? (5) What relationship do age and gender have on a student's achievement level, as measured by the final course average, considering textbook format?

\section{Literature review}

This literature review presents findings from efficacy studies on student and faculty perceptions of electronic versus paper textbooks and the current literature on the LoU framework.

\section{Student perceptions of E-textbooks}

While the majority of studies indicate no difference in student performance between e-textbooks and paper textbooks (Daniel and Woody, 2012; Shepperd et al., 2008; Taylor, 2011), and while the use of mobile devices is highly prevalent among today's students (Chen and Denoyelles, 2013; Rockinson-Szapkiw et al., 2013), the acceptance of e-textbooks is in an early stage of migration. In a study by Woody et al. (2010), undergraduate students in a general psychology course were surveyed regarding their satisfaction with e-books, their usage of e-book features and their comfort level with computers. Results indicated that the use of e-books was not affected by comfort level with computers or by gender. The study found that although e-books offered special features such as embedded links and web activities, e-book users were not more likely to engage in these activities. A similar result was found in Daniel and Woody's (2012) study of e-textbooks. There was no difference in the rate of completion for learning activities as a function of media type (Daniel and Woody, 2012).

When Walton (2007) investigated students' use of e-books for conducting research, as a textbook, and for leisure reading, he found the majority of students prefer paper books to e-books at the small liberal arts institution. Students preferred using traditional books to e-books for conducting research at a ratio of 2.3 to 1 . Students preferred a traditional textbook 
format to e-book format at a ratio of 3.6 to 1 . Finally, students overwhelmingly preferred using paper books over e-books for leisure reading at a ratio of 30.3 to 1 . Walton (2007) suggests these ratios may be driven by the relative advantage of e-books compared to paper books. While e-books have a greater relative advantage due to factors such as digitization, portability and search-ability, they are also seen as less advantageous because they are "hard on the eyes, not easy to read" (p. 96) and "are tied to the computer screen's location" (p. 96) in some instances. The preference ratio could also be attributed to reading patterns. Walton (2007) postulates that students are not reading e-books cover to cover, but rather using them as a tool for research by using the search feature and reading small portions of the text in which they are interested.

In contrast to Walton's (2007) findings, Weisberg (2011) found an increasing reception to and acceptance of e-textbooks. In this two-year longitudinal study, students' attitudes and behavior toward e-textbooks were evaluated in undergraduate students in a management strategy course. Data were collected by student surveys, observations and learning assessments. From 2009 to 2011, observable changes in students' attitudes and behaviors were found. Initially, students were unfamiliar with the e-readers and e-textbook devices assigned to them and felt that these devices were not conducive to the classroom yet. The following year, several students reported enjoying using the e-textbooks and stated it was their preferred way of reading their text. In the final year of the study, an increase in the technology readiness and awareness of the students was seen. Weisberg (2011) found that "The number of students who reported that they would not use an eReader device for their textbook even if it were available, decreased by over $50 \%$ over the duration of the class to less than $10 \%$ of the students" (p. 193). Three major factors were identified as the force behind the increase in and acceleration of student acceptance and use of e-textbooks. These were cost, the impact on learning and whether e-textbooks were assigned or recommended by the instructor.

Other studies also support the impact of the instructor on e-textbook preferences among students. Stone and Baker-Everleth (2013) surveyed students in a mid-sized university in the western USA. The research concluded that ease-of-use of e-textbooks had "positive, meaningful affects on students' attitudes toward e-textbooks and behavioral intentions to purchase e-textbooks" (Stone and Baker-Everleth, 2013, p. 44). In addition, verbal persuasion/ social norms had a positive influence on students' attitudes toward and intentions to use e-textbooks. In other words, encouragement to use e-textbooks by faculty, parents and classmates could promote a positive attitude toward and acceptance of e-textbooks.

\section{Preferences by discipline}

Studies have found no significant difference in student outcomes between the electronic and print texts controlling for gender (Woody et al., 2010) or age (Ditmyer et al., 2012). However, research indicates student preferences for text format do differ by discipline. A study of 313 undergraduate students by Ciampa et al. (2013) concluded that non-business majors were more satisfied with e-textbooks and more likely to use them again in the future compared to business majors.

It appears e-textbooks have found a niche as reference books with many students; thus, disciplines in the medical field find e-textbooks particularly attractive. A study of first-year medical students at the University of Central Florida College of Medicine found that students reported a higher level of motivation using interactive e-textbooks over printed books (Gillum et al., 2014). Students favored the interactive e-textbook "because of its ease of navigation and access, self-assessment features, and its interactivity and search capabilities" (Gillum et al., 2014, para. 5).

The Medical Sciences Library at Texas A\&M University studied the use of core medical texts in electronic and print format (Ugaz and Resnick, 2008). For the 51 titles analyzed in

E-textbook technology 
JRIT

14,3

their reference/core collection during 2005-2006, electronic editions were used substantially more than printed editions. This could be the result of mobile learners in mobile learning environments. In addition to serving traditional classroom students, the library served geographically dispersed medical students completing their third and fourth years of clinical residency. The 12,132 uses of electronic editions over the 278 uses of print editions ultimately led the library to designate the e-book version as the primary reference copy.

Faculty perceptions of e-textbooks

Studies on faculty perceptions of e-textbooks reveal the same pattern as that of students. Initially, there is an aversion to e-textbooks followed by more acceptance over time. For example, Walton (2007) found that only $8 \%$ of faculty indicated a preference for e-books over paper books for conducting research. This study also found that $0 \%$ of faculty preferred e-books as a textbook and $0 \%$ preferred e-books for leisure reading.

Bossallar and Kammer (2014) conducted narrative interviews with eight faculty members across various disciplines regarding their experiences with e-textbooks. Results indicated that the instructors were concerned about the affordability of learning content and thus, the cost of the e-textbook was a factor when determining what materials would be used. Regarding the loss of access to e-textbook content after the course, participants expressed mixed opinions. Some instructors felt continued access was important for future courses, whereas others cited the availability of online information as reducing the need to retain access. There was concern regarding the technical support role instructors sometimes had to play; however, 24/7 customer support was generally available from the publishers. E-textbook platforms allow instructors to monitor student use of the text. For example, instructors can track a student's number of unique visits, number of pages viewed, number of pages printed, number of highlights made and number of notes made. While some instructors expressed concerns about privacy, others saw value in the ability to track student activity to assess performance and provide assistance.

Some educators not only advocate the use of digital textbooks in their courses, they also encourage writing and using open source content (Allen, 2014). Stewart (2009), a professor in Oceanography and an author of free, online oceanography textbooks, identified several benefits to online textbooks. One benefit is that electronic publication allows for quicker and easier revision. The publication process for traditional textbooks can take 2 to 3 years after writing is complete. By then, the material is out of date, especially in scientific fields where discoveries might be made every few months. Furthermore, open-source textbooks published under a creative commons license allow instructors to personalize the material. For example, chapter content may be added, removed or rearranged. Another benefit is the growing availability of multimedia materials that can be inserted into online texts. Stewart (2009) states "A short film clip of the tsunami coming ashore at Banda Aceh in Indonesia on December 26,2004, is much more effective in showing the power of a tsunami than any words I might write" (p. 24).

Ciampa et al. (2013) found a significant, positive relationship between students' use of e-textbook features and their satisfaction with the e-textbook. Instructor use of e-textbook features could influence student use of the features and thus increase student satisfaction with e-textbooks. Learnings from Indiana University support this finding as well. Their e-textbook initiative showed students had more positive experiences when instructors actively used features such as highlighting and sharing. Student survey results from the pilot program showed that $70 \%$ of students considered the use of these features an important factor in their preference for and adoption of e-textbooks (Lewis, 2018). Ciampa et al. (2013) advocated for educators and e-textbook publishers to "expose students to the special features incorporated as part of an e-textbook" (p. 8) through demonstrations and use during class, which leads to this study's framework of LoU of an innovation. 
E-textbook adoption and the levels of use framework

The transition to an e-textbook initiative can be viewed as the adoption of a technological innovation. Thus, the framework for this study was Hall et al.'s (1975) LoU for analyzing innovation adoption. LoU, along with Stages of Concern and Innovation Configurations, is a dimension of the overarching Concerns-Based Adoption Model (CBAM) proposed by Hall et al. (1973). CBAM contends that teachers are the key adopters of interest in the evaluation of an educational change innovation (Ellsworth, 2000). Subsequently, LoU can be used as a tool for mapping "the adopter's behavioral progress in putting the innovation into practice" (Ellsworth, 2000, p. 149).

CBAM is a framework for exploring the affective and behavioral changes of key adopters during the adoption of educational innovations (Ellsworth, 2000). One of the central constructs of this model is that the existence of an innovation does not guarantee its use (Hall et al., 1973). Another key construct of the model is that adoption of the innovation does not occur at a single point in time, but rather is as a process. As such, the variation in adoption by individual users can be described and profiled over time to identify strategies that will yield the most effective adoption (Hall et al., 1975). The LoU index consists of eight potential states for the use of an innovation ranging from unawareness of the innovation to effective use of the innovation, including a search for even better innovations. Table 1 depicts the LoU chart. For over four decades, the CBAM LoU procedure has been used in a variety of contexts ranging from education (Orr and Mrazek, 2010) to service sectors (Bedell et al., 1985) and to industry (Schaafsma, 1995).

This study added to the body of knowledge regarding e-textbook efficacy. While other studies used an experimental approach to the evaluation of e-textbooks and traditional textbooks, this study contributed to the body of knowledge by evaluating student grade data during the transition period from paper to e-textbooks at a community college. While many studies stop with the conclusion that there is no difference in student outcomes between text formats, this study addressed a gap in literature on how to improve student performance with e-textbook technology. This was done by using the LoU of an innovation framework to determine instructors' LoU of e-textbook features, whether there was a difference in LoU profiles across programs of study; what factors were related to higher LoU; and what improvements or programs could be implemented to increase LoU and student learning.

\section{Methods}

\section{Sample}

Participants of this study were instructors in a large-sized (5,000-9,999 students), two-year, public institution in a community college system in a southeastern state. The institution offers Associates degrees for exclusively undergraduate two-year programs. Programs of study are offered in four divisions: Business/Computer Information Systems (CIS), Technology and Workforce Development; Health; Humanities and Social Sciences; and Mathematics and Natural Sciences. Permission for the study was obtained from the investigator's institutional review board, and consent was received from the institution of study.

\section{Instructor sample demographics}

The LoU survey was sent to 57 instructors who taught with an e-textbook during the 20142015 pilot period. While a $100 \%$ response rate is ideal, factors such as lack of availability and interest may result in a lower response rate. Fink (2009) states that a response rate of $70 \%$ may be considered adequate. Given that participation in this study was voluntary with no direct benefit to participants, a lower response rate was expected. Thirty-one instructors completed the survey, yielding an actual response rate of $54 \%$. Of those 31 instructors, 14

E-textbook technology

\section{technology}

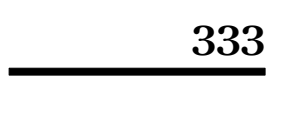




\section{JRIT 14,3}

334
Level of use Description

0 (non-use) User has little or no knowledge of the innovation, no involvement with the innovation and is doing nothing toward becoming involved

Decision Point A: Takes action to learn more detailed information about the innovation

I (orientation) User has acquired or is acquiring information about the innovation and/or has explored or is exploring its value orientation and its demands upon user and user system

Decision Point B: Makes a decision to use the innovation by establishing a time to begin II (preparation) User is preparing for first use of the innovation

Decision Point C: Begins first use of the innovation

III (Mechanical User focuses most effort on the short-term, day-to-day use of the innovation with little use) time for reflection. Changes in use are made more to meet user needs than client needs. The user is primarily engaged in a stepwise attempt to master the tasks required to use the innovation, often resulting in disjointed and superficial use

Decision Point D-1: A routine pattern of use is established

IV (A routine) Use of the innovation is stabilized. Few if any changes are being made in ongoing use. Little preparation or thought is being given to improving innovation use or its consequences

Decision Point D-2: Changes use of the innovation based on formal or informal evaluation to increase client outcomes

IVB (Refinement) User varies the use of the innovation to increase the impact on clients within immediate sphere of influence. Variations are based on knowledge of both short-term and long-term consequences for clients

Decision Point E: Initiates changes in the use of innovation based on the input of and in coordination with what colleagues are doing

$\mathrm{V}$ (integration) User is combining own efforts to use the innovation with related activities of colleagues to achieve a collective impact on clients within their common sphere of influence

Decision Point F: Begins exploring alternatives to or major modifications of the innovation presently in use VI (Renewal) User reevaluates the quality of use of the innovation, seeks major modifications or alternatives to present innovation to achieve increased impact on clients, examines new developments in the field and explores new goals for self and the system

Table 1. LoU chart

Source(s): Hall et al. (1975)

were male (45.2\%) and 17 were female (54. $8 \%$ ). The majority of instructors had a master's degree as their highest level of education $(n=20,64.5 \%)$. Instructors were primarily aged $40-49(n=12)$ or over $60(n=9)$. Most instructors were experienced college professors, teaching on average 13 years $(\mathrm{SD}=8.5$, range $1-33)$. Instructors reported an average of 3.6 professional development experiences $(\mathrm{SD}=4.0$, range $0-15)$ involving e-textbooks. The average number of semesters taught with e-textbooks ranged from 0 to 10 with an average of $2.9(\mathrm{SD}=2.2)$. Table 2 provides descriptive statistics of the instructors.

\section{Data collection}

There were two forms of data collection for this study. To address the first three research questions, a survey was administered to instructors to identify the LoU index for various e-textbook features and innovations. This information provides insight into the extent of the adoption of e-textbook innovations by college instructors.

Furthermore, historical data were extracted from the college's Student Information System (Banner $\left.{ }^{\circledR}\right)$ to answer the last two research questions. Final grades were reported as letter grades (e.g. A - excellent, B - good, C - average, D - poor, F - failure, I - incomplete 


\begin{tabular}{|c|c|c|c|c|}
\hline $\begin{array}{l}\text { Assigned numerical } \\
\text { value for analysis }\end{array}$ & $\begin{array}{l}\text { Level of use } \\
\text { state }\end{array}$ & Classification & Stem descriptor & $\begin{array}{l}\text { E-textbook } \\
\text { technology }\end{array}$ \\
\hline 1 & 0 (non-use) & Non-use & My e-textbook does not offer this feature & \\
\hline 1 & 0 (non-use) & Non-use & I really do not know anything about this feature & \\
\hline 1 & 0 (non-use) & Non-use & $\begin{array}{l}\text { I am not sure that this feature would be useful for } \\
\text { my class }\end{array}$ & \\
\hline \multirow[t]{2}{*}{2} & \multirow[t]{2}{*}{ I (orientation) } & \multirow[t]{2}{*}{ Low-level use } & \multirow{2}{*}{$\begin{array}{l}\text { I have some information about this feature, and I } \\
\text { am considering whether it might be useful for my } \\
\text { class }\end{array}$} & 335 \\
\hline & & & & \\
\hline 3 & II (preparation) & Low-level use & $\begin{array}{l}\text { I now know enough about this feature that I am } \\
\text { preparing to use it for my class }\end{array}$ & \\
\hline 4 & $\begin{array}{l}\text { III (Mechanical } \\
\text { use) }\end{array}$ & Mid-level use & $\begin{array}{l}\text { I am using this feature now and am primarily } \\
\text { focused on learning the skills necessary to use it } \\
\text { properly and effectively for my class }\end{array}$ & \\
\hline 5 & IVA (routine) & Mid-level use & $\begin{array}{l}\text { I use this feature routinely without much } \\
\text { conscious thought, and my use of this technology } \\
\text { is fairly routine for my class }\end{array}$ & \\
\hline 6 & $\begin{array}{l}\text { IVB } \\
\text { (Refinement) }\end{array}$ & $\begin{array}{l}\text { High-level } \\
\text { use }\end{array}$ & $\begin{array}{l}\text { I use this feature regularly, and I am implementing } \\
\text { ways of varying its use to improve the outcomes } \\
\text { derived for my class }\end{array}$ & \\
\hline 7 & V (integration) & $\begin{array}{l}\text { High-level } \\
\text { use }\end{array}$ & $\begin{array}{l}\text { I am collaborating with colleagues to develop } \\
\text { ways in which we can use this feature to better } \\
\text { meet our common objectives for our classes }\end{array}$ & \\
\hline 8 & VI (Renewal) & $\begin{array}{l}\text { High-level } \\
\text { use }\end{array}$ & $\begin{array}{l}\text { I still use this feature but I am exploring other } \\
\text { technologies to replace it that will better meet the } \\
\text { objectives for my class }\end{array}$ & $\begin{array}{r}\text { Table } 2 . \\
\text { LoU descriptions }\end{array}$ \\
\hline
\end{tabular}

or W - withdrawal). Students who did not complete the course and thus earned grades of "I" or "W" were excluded from the analyses. To numerically analyze the data, a letter grade of "A" was assigned a value of 4, a "B" was assigned a value of 3 , a "C" was assigned a value of 2 , a "D" was assigned a value of 1 and an " $F$ " was assigned a value of 0 .

\section{Instrumentation}

Instructors were asked to self-report demographic data such as gender, age range, highest degree earned, number of years of college-level teaching, number of professional development experiences with e-textbooks and number of semesters taught with an e-textbook. A modified version of Hall et al.'s (1975) LoU interview protocol, adapted by Orr and Mrazek (2010), was used for instructors to self-assess their LoU with eight features of e-textbooks. The eight e-textbook features evaluated included the following:

\footnotetext{
highlighting text and sharing,

making notes and sharing,

exporting text or notes,

tracking and analysis of e-textbook use,

interactive practice questions or games,

web links,

videos/animations, and
}

just-in-time (JIT) learning or performance support. 
JRIT
14,3

336
The LoU descriptors used in this study are shown in Table 3. For each of the eight e-textbook features of study, instructors were given this same set of LoU descriptors from which to choose a response. Each of the stem descriptors for the LoU survey was assigned a numerical value as also shown in Table 3 . The numerical values were not visible to survey participants to avoid a presumed hierarchical progression of responses. An overall LoU value was calculated for each e-textbook feature by averaging the numerical value of each participant's ranking for that feature. The corresponding LoU state was then used to characterize users as non-users, low-level users, mid-level users and high-level users. Users with overall LoU states of 0 were classified as non-users. Users whose overall average fell within Levels I and II were acquiring information to prepare for use and were classified as low-level users. At Levels III and IVA, use has become routine and stabilized. Thus, these users were classified as mid-level users. Finally, Levels IVB, V and VI represented high-level users who are collaborating with others and exploring alternatives to improve the experience for the client.

\section{Results and discussion}

Research question 1: Instructor levels of use of E-textbook features

Results showed that on average six e-textbook features were Level 1 (Orientation). These six features were highlighting text and sharing, making notes and sharing, exporting text or notes, interactive practice questions or games, web links and videos/animations. Two features were Level 0 (non-use) on average. These features were tracking and analysis of e-textbook use and just-in-time learning or performance support. The overall non-existent to low LoU of features may indicate instructors are not using e-textbooks any differently than paper textbooks; thus, e-textbooks would be mere PDF documents of print textbooks. Previous research indicated these static mediums are not perceived favorably by students

\begin{tabular}{|c|c|c|}
\hline & $n$ & $\%$ \\
\hline \multicolumn{3}{|l|}{ Gender } \\
\hline Male & 14 & 45.2 \\
\hline Female & 17 & 54.8 \\
\hline \multicolumn{3}{|l|}{ Age } \\
\hline $20-29$ years & 3 & 9.7 \\
\hline $30-39$ years & 4 & 12.9 \\
\hline $40-49$ years & 12 & 38.7 \\
\hline $50-59$ years & 3 & 9.7 \\
\hline$\geq 60$ years & 9 & 29.0 \\
\hline \multicolumn{3}{|l|}{ Degree } \\
\hline Associate's & 0 & 0 \\
\hline Bachelor's & 4 & 12.9 \\
\hline Master's & 20 & 64.5 \\
\hline Doctorate & 7 & 22.6 \\
\hline \multicolumn{3}{|l|}{ Division } \\
\hline Humanities and Social Sciences & 14 & 45.2 \\
\hline Mathematics and Natural Sciences & 13 & 41.9 \\
\hline Business/CIS & 4 & 12.9 \\
\hline Health & 0 & 0 \\
\hline Years of college-level teaching & \multicolumn{2}{|c|}{$M=13.0(S D=8.5)$} \\
\hline Number of professional development experiences & \multicolumn{2}{|c|}{$M=3.6(S D=4.0)$} \\
\hline Number of semesters using e-textbooks & & \\
\hline
\end{tabular}

Number of professional development experiences
Table 3. Demographic statistics for instructors 
(Shepperd et al., 2008). Research by Stone and Baker-Everleth (2013) concluded that instructors' verbal persuasion to use e-textbook features had a positive influence on students' attitudes toward and intentions to use e-textbooks. In this case, if instructors are not incorporating the features into their methods of teaching, they are likely not encouraging students to use the features either. Research has also shown that this lack of use of e-textbook features by students may be related to a lack of satisfaction with e-textbooks (Ciampa et al., 2013).

Some non-use of e-textbook features can be attributed not to an instructor's lack of training or initiative but instead to the lack of availability of that feature. The growing market of digital learning content has forced textbook publishers to reevaluate their business models and whether they will be content experts or platform experts (Reynolds, 2012). As such, some textbooks do not offer the interactivity of others. In this study, nine instructors $(29 \%)$ reported their e-textbook did not offer videos/animations. Five instructors $(16.1 \%)$ reported their e-textbook did not offer interactive practice questions or games. Five instructors $(16.1 \%)$ also reported their e-textbook did not offer web links.

Among the eight features evaluated, just-in-time learning or performance support was the feature overwhelmingly not used by instructors $(n=26,83.9 \%)$. The overall non-use of justin-time learning or performance support indicates instructors and students may not be exploiting the mobility of e-textbooks. Access to e-textbooks on mobile devices by mobile learners creates new learning opportunities. These include situated learning and collaborative learning in a learner-centric environment outside the classroom (Traxler, 2009). The college may want to consider exploring mobile learning pedagogy with instructors, given the ubiquity of mobile devices and students' expectations to access their instructional materials on mobile devices (Smith and Caruso, 2010). A frequency distribution of LoU classification by feature is shown in Figure 1.

The low LoU values for features should not be construed as negative. The LoU model is not intended to be a performance evaluation, but a method of quantifying behaviors and actions. The LoU values represent one point in time during the college's e-textbook pilot period and can serve as a baseline for future measurements.

\section{LoU of E-textbook Features}

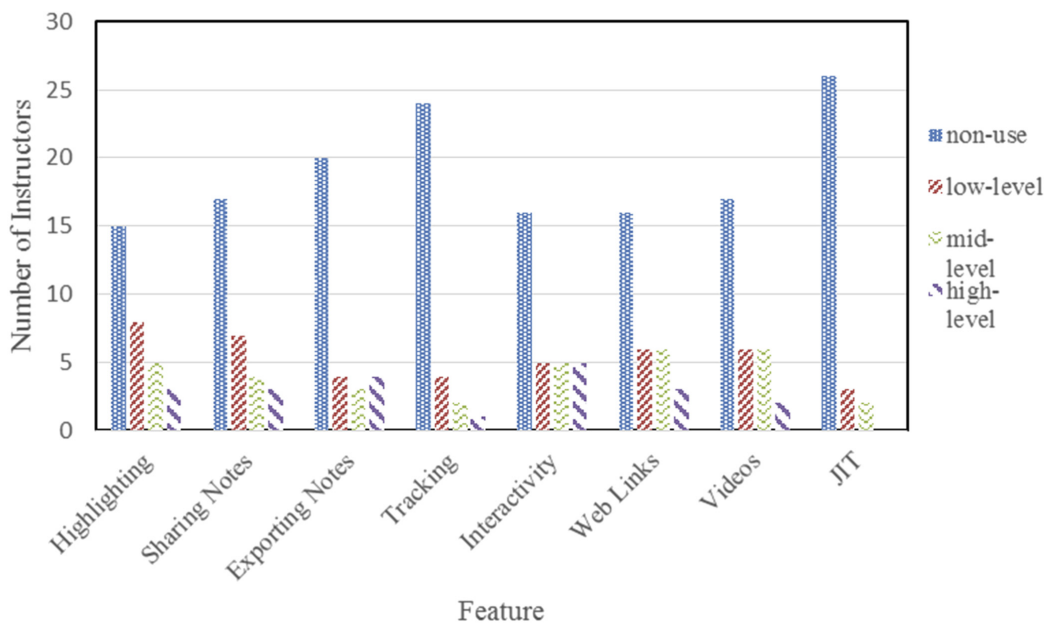

Figure 1.

Frequency distribution of LoU classifications by feature
E-textbook technology 
JRIT

14,3

338

Research question 2: Differences in levels of use among programs of study

This research question sought to determine if there were differences in instructor LoU among the school's four programs or divisions. The mean LoU for Humanities and Social Sciences was $1.83(\mathrm{SD}=0.63)$, while Math and Natural Sciences was 2.31 $(\mathrm{SD}=0.85)$ and Business/CIS was $2.22(\mathrm{SD}=0.99)$. Unfortunately, there were no LoU responses from the division of Health for comparison. Due to the small number of responses from the Business/CIS division, only differences between the division of Humanities and Social Sciences and the division of Math and Natural Sciences were analyzed for significance, using a nonparametric statistical procedure for independent samples. The Mann-Whitney $U$-test revealed no significant difference in the LoU values $(z=-1.63, p=0.10)$. It appears $\mathrm{LoU}$ is similar among instructors and no single division is excelling in the integration of e-textbook features. While the $p$-value did not show significance, the effect size of 0.31 indicated a medium association between the two programs. Therefore, a potential difference in LoU exists between the division of Humanities and Social Sciences and the division of Math and Natural Sciences, but the small sample size may have limited the ability to detect a difference.

It should be noted that these results represent a single self-assessment of instructors at a single point in time of the e-textbook initiative. Paramount to the CBAM and LoU frameworks is the principle that the successful adoption of an innovation is a process that occurs over time. As such, the college may find value in conducting prescribed interventions and repeating the evaluation.

Research question 3: Instructor demographic characteristics and levels of use

ANOVA test results showed no significant difference in LoU by age $\left(F_{(4.26)}=1.04, p=0.41\right)$, gender $\left(F_{(1.29)}=2.36, p=0.59\right)$ or education level $\left(F_{(2.28)}=0.90, p=0.42\right)$.

Two variables were selected for multiple linear regression: Years of teaching and number of professional development experiences. These variables had been found to have positive relationships with LoU in previous studies. The Pearson correlation coefficient revealed a weak, negative relationship between LoU and years of teaching $(r=-0.01, p=0.48$, $\left.R^{2}=0.0001\right)$. There was a moderate, positive relationship between LoU and number of professional development experiences $\left(r=0.35, p=0.03, R^{2}=0.122\right)$. Regression analysis revealed the number of professional development sessions was a significant predictor of $\mathrm{LoU}$, controlling for years of teaching $(t(28)=2.17, p=0.04)$.

The e-textbook study found a weak, negative relationship between years of teaching and instructor LoU. This may indicate the relationship between LoU and years of teaching is context-specific. While some technologies may be more readily adapted by experienced teachers, others are more readily adapted by less experienced and perhaps younger teachers. The e-textbook study found a significant, positive relationship between professional development opportunities and LoU.

\section{Research question 4: Comparison of student performance between text formats}

After identifying instructors' LoU of e-textbook features, the study then investigated student learning with e-textbooks during the pilot period. With assistance from the institution's Distance Learning Coordinator, 27 cases were identified for comparison. Sample selection criteria for course comparisons were as follows: (1) The same instructor taught both an e-textbook section of the course and a traditional print section of the course; (2) the same textbook was used in the e-textbook section of the course and the traditional print section of the course; (3) the same class format (classroom, online and hybrid) was used for the e-textbook section and the traditional print section; and (4) The instructor used the same assessment measures in the e-textbook section and the traditional print section, as determined by the grading plan of the syllabus. In all cases, there was no difference in final 
course grades between e-textbook and paper textbook sections. This finding aligns with the majority of research studies on e-textbook efficacy (Daniel and Woody, 2012; Shepperd et al., 2008; Taylor, 2011). A positive finding from the e-textbook trial is that student grades were not negatively impacted during the pilot period.

There were two cases showing a marginally significant difference in performance between the text formats using an alpha controlled for the family-wise error rate of 0.002. A comparison of Theatre Appreciation showed the e-textbook grade average $(M=2.31$, $\mathrm{SD}=1.60)$ was lower $(\phi=0.002)$ than the paper text section $(M=2.96, \mathrm{SD}=1.33)$ with a 0.47 effect size (medium). A comparison of Art History I showed the e-textbook grade average $(M=2.23, \mathrm{SD}=1.39)$ was lower $(p=0.002)$ than the paper text section $(M=3.09, \mathrm{SD}=0.98)$ with a 0.74 effect size (medium to large). This finding supports previous research which suggests some subjects are more amenable to the electronic format than others (Bailey, 2006). Data collected from the libraries of several large, higher education institutions reveal that the most popular subjects for electronic access were computer science, technology/engineering, economics/business, medicine/health/wellness and literature. Dillon (2001) postulates that subjects such as these "lend themselves to the quick reference-style look-ups that are already part of Web behavior" (p. 119). The libraries found that subjects such as film/media studies and fine arts had little to no electronic use during the study period (Bailey, 2006). Based on these findings, leaders should exercise prudence when implementing institution-wide mandates for e-textbook use.

\section{Research question 5: Impact of age and gender on student performance}

The three-way ANOVA for the last research question required 128 students, or 16 students per group, to achieve a power of 0.8 , using an effect size of 0.25 (medium) and a significance level of 0.05 (Faul et al., 2007). This analysis was based on two levels of text format (e-textbook and paper), two levels of gender (male and female) and two levels of age category (traditional and non-traditional). The actual sample size was 2,432 students. From the data set of 27 courses used in Research question 4, student demographic and grade data were collected for all 2,432 students. Overall, 1,424 students $(58.6 \%)$ were enrolled in e-textbook sections and 1,008 students $(41.4 \%)$ were enrolled in print textbook sections. For the student sample, 837 were male (34.4\%) and 1,595 were female (65.6\%). The average student age was 24.8 with $79.4 \%$ of the students being age 29 or younger and $92.2 \%$ being age 39 or younger. Student age ranged from 15 to 71 years. Table 4 provides a detailed breakdown of student demographics.

The impact of age was evaluated by dichotomously classifying students as either of traditional age (24 years and younger) or non-traditional age (25 years and older). Results of a factorial ANOVA analysis revealed an interaction between age, gender and text format. When considering e-textbooks, non-traditional age female scores $(M=2.94, S E=0.08)$ were higher than non-traditional age male scores $(M=2.38, S E=0.12)$. Furthermore, nontraditional age males earned higher grades with paper textbooks $(M=2.78, S E=0.14)$ compared to e-textbooks $(M=2.38, S E=0.13)$. In the paper textbook sections, nontraditional age students $(M=2.81, S E=0.08)$ outperformed traditional age students $(M=2.61, S E=0.06)$. Figure 2 shows a plot of the means.

In this study, performance levels indicated varying success rates between text formats among the demographic characteristics. This finding counters previous research in which there was no difference in outcomes based on age or gender (Ditmyer et al., 2012; Woody et al., 2010). Course grades of males and females in the traditional age group using e-textbooks were comparable. This may not be surprising given that both genders are receiving exposure to digital curriculums at early ages as more and more school systems across the nation move to all-digital learning environments (Grunwald Associates LLC, 2013). However, the data
E-textbook technology 
JRIT
14,3

Table 4.

Demographic statistics

for students

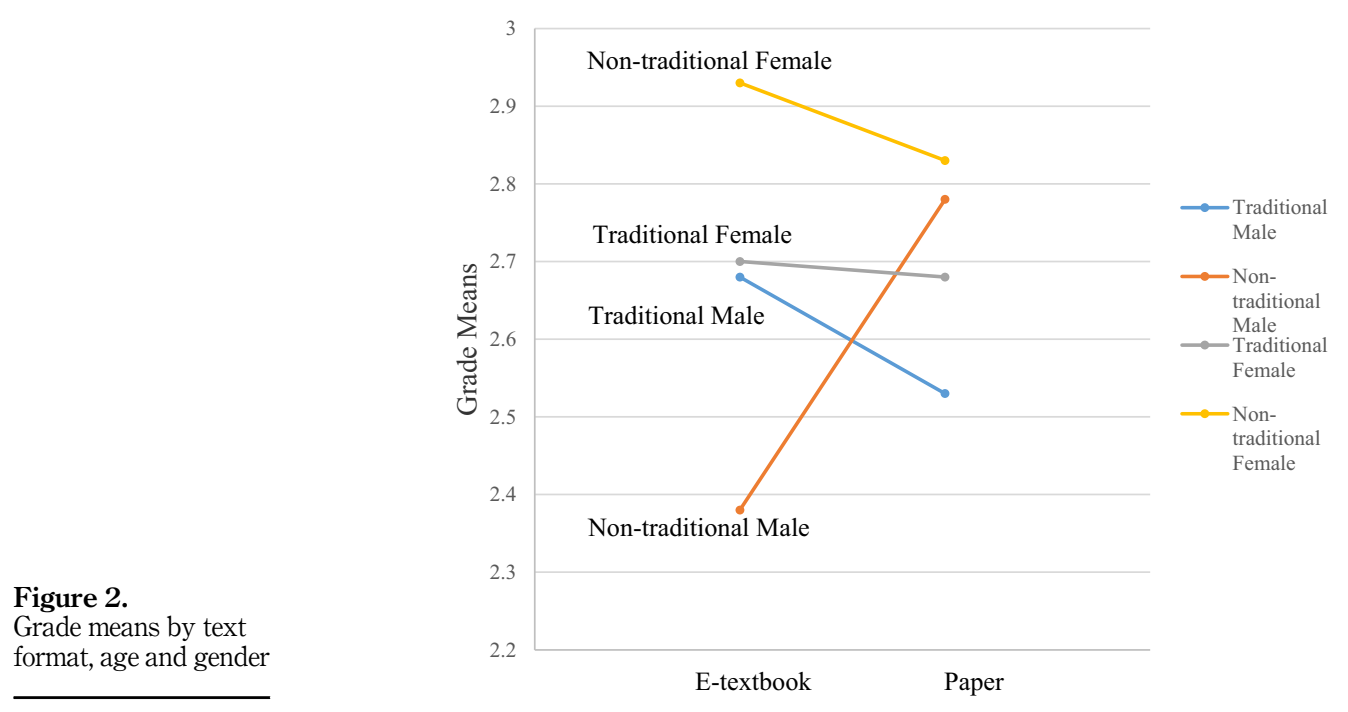

Figure 2.

Grade means by text format, age and gender

\begin{tabular}{lrr}
\hline & $n$ & $\%$ \\
\hline Textbook format & & \\
E-textbook & 1,424 & 58.6 \\
Paper & 1,008 & 41.4 \\
Gender & & \\
Male & 837 & 34.4 \\
Female & 1,595 & 65.6 \\
Age & & \\
$<20$ years & 752 & 30.9 \\
$20-29$ years & 1,180 & 48.5 \\
$30-39$ years & 311 & 12.8 \\
40-49 years & 132 & 5.4 \\
50-59 years & 48 & 2.0 \\
Z60 years & 9 & 0.4 \\
$M=24.8$ (SD 8.4) & & \\
Ethnicity & & 2.2 \\
American Indian or Alaskan native & 54 & 2.3 \\
Asian & 56 & 0.1 \\
Black/African American & 405 & 3.8 \\
Hawaiian or other Pacific Islander & 3 & 3.3 \\
Hispanic & 93 & 0.6 \\
Multi-racial & 80 & 2.1 \\
Non-resident Alien & 14 & 69.0 \\
Unknown & 50 & \\
White & 1,677 & \\
& & \\
& &
\end{tabular}

White

Textbook format

E-textbook

8.6

1.4

34.4

65.6

30.9

48.5

12.8

5.4

2.0

0.4

2.2

2.3

16.7
0.1

3.8

3.3

0.6

2.1 
collected during this pilot period indicated non-traditional age males using e-textbooks may warrant further study.

Education systems should be mindful of the amalgam of digital natives and digital immigrants in the classroom. Prensky (2001) defines digital natives as "native speakers' of the digital language of computers, video games and the internet" (p. 1), while digital immigrants are those who have adopted these new technologies. While some critique such demarcation and consider the concept of the digital native flawed (Koutropoulos, 2011), the community college of study must consider that it embodies learners from ages of 15-71 years old. As such, the range of technological exposure, comfort and skill level will vary. Any academic support services the college offers regarding e-textbooks should strive to normalize success potential among the broad span of age groups.

\section{Limitations}

This study was limited in scope to the cross-sectional design of responses from voluntary participants at one community college in a southeastern US community college system. Thus, results may not be generalizable to the entire population of higher education institutions. Another limitation of the study included a relatively low response rate from the LoU survey design, thus impacting the ability to achieve an adequate sample size for inferential statistical analysis. While a non-experimental research design was used to determine if there was a difference in course performance between e-textbook and paper textbook sections, measures were taken to control for extraneous variables.

\section{Conclusions and recommendations}

This study revealed e-textbook features were used at a low to non-existent level by instructors and there were no differences in instructor LoU across the programs of the study analyzed. Neither age, gender, rank or years of college-level teaching was related to LoU; however, instructors' number of e-textbook professional development experiences was a significant predictor of LoU.

The following recommendations are suggested for this institution and others, as they make strategic decisions regarding e-textbook initiatives. The first recommendation is to conduct professional development specifically targeted toward e-textbook features. One of the underlying assumptions of CBAM is that "change can be facilitated by interventions directed toward the individuals, innovations, and contexts involved" (Anderson, 1997, p. 333). In this study, instructors reported between three and four professional development experiences related to e-textbooks; however, the type, content and quality of the professional development are unknown. Thus, higher LoU of the technology could emerge after specifically planned interventions. Another learning from the Fairfax County School system was to give teachers "substantial time to learn the features and resources of a new, digital platform before sharing it with students" (Axelson, 2015, p. 10). Thus, professional development coupled with implementation time could prime the path for digital success.

The second recommendation is to evaluate the current menu of e-textbooks. Some instructors reported their e-textbooks did not offer highlighting and sharing capability, interactivity, web links or videos. This school and others may want to explore alternate textbooks that offer these features. This might be accomplished through other publishers and vendors or through Open Educational Resources (OER). OER allow instructors to personalize the curriculum and embed desired multimedia links (Allen, 2014).

The second part of the study evaluated student learning during the e-textbook initiative. There was no difference in student grades between e-textbook and paper textbook sections in any of the cases analyzed. Therefore, the pilot period did not have a negative impact on
E-textbook technology 
JRIT

14,3

student performance and demonstrated that students could be equally successful with both textbook formats. The third recommendation is to educate students on e-textbook features and functions. After an institution has the infrastructure and support structure for an e-textbook initiative, and after instructors have had time to adopt the technology, e-textbook features should be demonstrated to students. This could occur during an orientation type of course or instructors could demonstrate the use during class. According to research, it is this type of encouragement to use e-textbook features that promotes student satisfaction with and utilization of e-textbooks (Ciampa et al., 2013).

As digital textbooks change with technology, continued research is necessary to determine changes in efficacy. As e-textbooks become more widely accepted and used, it is important to understand how student learning can be improved through technology innovations offered in e-textbooks. Thus, this study determined instructors' LoU rankings with various e-textbook features. The low $\mathrm{LoU}$ of e-textbook features indicates there is a potential to have a positive impact on student learning, as the features and functions of e-textbooks are leveraged for student success.

\section{References}

Allen, N. (2014), "Advocating for change: open textbooks and affordability [Webinar]", NISO TwoPart Webinar: E-Books for Education, available at: http://www.niso.org/news/events/2014/ webinars/plug_in/ (accessed 19 May 2021).

Anderson, S.E. (1997), “Understanding teacher change: revisiting the concerns based adoption model”, Curriculum Inquiry, Vol. 27 No. 3, pp. 330-367.

Axelson, M. (2015), “Digital textbook reflections”, eSchool News, Vol. 18 No. 1, pp. 10-11.

Bailey, T.P. (2006), "Electronic book usage at a master's level I university: a longitudinal study”, The Journal of Academic Librarianship, Vol. 32 No. 1, pp. 52-59.

Bedell, J.R., Ward, J.C. Jr, Archer, R.P. and Stokes, M.K. (1985), “An empirical evaluation of a model of knowledge utilization", Evaluation Review, Vol. 9, pp. 109-126.

Bossaller, J. and Kammer, J. (2014), "Faculty views on eTextbooks: a narrative study", College Teaching, Vol. 62 No. 2, p. 68, doi: 10.1080/87567555.2014.885877.

Chen, B. and Denoyelles, A. (2013), Exploring Students' Mobile Learning Practices in Higher Education, available at: http://www.educause.edu/ero/article/exploring-students-mobile-learning-practiceshigher-education (accessed 19 May 2021).

Ciampa, M., Thrasher, E., Marston, S. and Revels, M. (2013), "Is acceptance of e-textbooks disciplinedependent? Comparing business and non-business student perceptions", Research in Higher Education Journal, Vol. 20, pp. 1-13.

Daniel, D.B. and Woody, W.D. (2012), "E-textbooks at what cost? Performance and use of electronic v. print texts", Computers and Education, Vol. 62, pp. 18-23.

Dillon, D. (2001), "E-books: the university of Texas experience, part 1", Library Hi Tech, Vol. 19 No. 2, pp. 113-125.

Ditmyer, M., Dye, J., Guirguis, N., Jamison, K., Moody, M., Mobley, C. and Davenport, W. (2012), "Electronic vs. traditional textbook use: dental students' perceptions and study habits", Journal of Dental Education, Vol. 76 No. 6, pp. 728-738.

Ellsworth, J.B., \& ERIC Clearinghouse on Information Technology, S.Y. (2000), Surviving Change: A Survey of Educational Change Models, ERIC Publications, Syracuse.

Faul, F., Erdfelder, E., Lang, A.-G. and Buchner, A. (2007), "G*Power 3: a flexible statistical power analysis program for the social, behavioral, and biomedical sciences", Behavior Research Methods, Vol. 39, pp. 175-191.

Fink, A. (2009), How to Conduct Surveys: A Step-by-step Guide, 4th ed., Sage, Thousand Oaks, California, CA. 
Gillum, S., Garner, M., Walson, D. and Dexter, N. (2014), Interactive E-Textbooks: Millennial Medical Students' Learning Preferences, available at: http://dcdm.doody.com/2014/01/interactive-etextbooks-millennial-medical-students-learning-preferences/ (accessed 19 May 2021).

Grunwald Associates LLC (2013), Living and Learning with Mobile Devices: What Parents Think about Mobile Devices for Early Childhood and K-12 Learning, available at: http://www.learningfirst. org/LivingandLearningwithMobileDevices (accessed 19 May 2021).

Hall, G.E., Wallace, R.C. and Dossett, W.A. (1973), A Developmental Conceptualization of the Adoption Process within Educational Institutions, Research and Development Center for Teacher Education, The University of Texas at Austin, Austin, Texas, TX.

Hall, G.E., Loucks, S.F., Rutherford, W.L. and Newlove, B.W. (1975), "Levels of use of the innovation: a framework for analyzing innovation adoption", Journal of Teacher Education, Vol. 26 No. 1, p. 52.

Koutropoulos, A. (2011), "Digital natives: ten years after", Merlot Journal of Online Learning and Teaching, Vol. 7 No. 4, pp. 525-538.

Lewis, D.W. (2018), eTexts 101: A Practical Guide, Pressbooks, The Trustees of Indiana University under a Creative Commons Attribution 4.0 International License.

Miller, J.R., Nutting, A.W. and Baker-Eveleth, L. (2013), "The determinants of electronic textbook use among college students", American Economist, Vol. 58 No. 1, pp. 41-50.

Orr, D. and Mrazek, R. (2010), "Developing the level of adoption survey to inform collaborative discussion regarding educational innovation", Canadian Journal of Learning and Technology/La Revue Canadienne De L'Apprentissage Et De La Technologie, Vol. 35 No. 2, available at: http:// files.eric.ed.gov/fulltext/EJ896568.pdf.

Prensky, M. (2001), "Digital natives, digital immigrants part 1", On the Horizon, Vol. 9 No. 5, pp. 1-6, doi: 10.1108/10748120110424816.

Reynolds, R. (2012), The Future of Learning Content: E-Textbooks, Open Content, Apple and beyond!, Next is Now Publishing, Columbia, MO.

Rockinson-Szapkiw, A.J., Courduff, J., Carter, K. and Bennett, D. (2013), "Electronic versus traditional print textbooks: a comparison study on the influence of university students' learning", Computers and Education, Vol. 63, pp. 259-266.

Schaafsma, H. (1995), "Monitoring training programmes using level of use interviews", Vocational Aspect of Education, Vol. 47, pp. 405-424.

Shepperd, J.A., Grace, J.L. and Koch, E.J. (2008), "Evaluating the electronic textbook: is it time to dispense with the paper text?", Teaching of Psychology, Vol. 35 No. 1, pp. 2-5.

Smith, S.D. and Caruso, J.B. (2010), Research Study, The ECAR Study of Undergraduate Students and Information Technology, 2010, EDUCAUSE Center for Applied Research, Boulder, CO, Vol. 6, available at: https://ibrary.educause.edu/resources/2010/10/ecar-study-of-undergraduatestudents-and-information-technology-2010 (accessed 19 May 2021).

Stewart, R. (2009), "Some thoughts on free textbooks", EDUCAUSE Review, Vol. 44 No. 1, p. 24.

Stone, R. and Baker-Eveleth, L. (2013), "Students' intentions to purchase electronic textbooks", Journal of Computing in Higher Education, Vol. 25 No. 1, pp. $27-47$.

Taylor, A. (2011), "Students learn equally well from digital as from paperbound texts", Teaching of Psychology, Vol. 38 No. 4, pp. 278-281.

Traxler, J. (2009), "Learning in a mobile age", International Journal of Mobile and Blended Learning, Vol. 1 No. 1, pp. 1-12.

Ugaz, A.G. and Resnick, T. (2008), "Assessing print and electronic use of reference/core medical textbooks", Journal of the Medical Library Association, Vol. 96, pp. 145-147.

Vassiliou, M. and Rowley, J. (2008), "Progressing the definition of 'e-book”, Library Hi Tech, Vol. 26 No. 3, pp. 355-368.

E-textbook technology (1) 
JRIT

14,3

344
Wakefield, J.F. (2006), “Textbook Usage in the United States: The Case of US History", Paper presented at the International Seminar on Textbooks, Santiago, Chile, available at: http://files.eric.ed.gov/ fulltext/ED491579.pdf.

Walton, E.W. (2007), Faculty and Student Perceptions of Using E-Books in a Small Academic Institution, Paper Presented at the ACRL 13th National Conference: Sailing into the FutureCharting Our Destiny, Baltimore, MD.

Weisberg, M. (2011), "Student attitudes and behaviors towards digital textbooks", Publishing Research Quarterly, Vol. 27 No. 2, pp. 188-196, doi: 10.1007/s12109-011-9217-4.

Woody, W., Baker, C. and Daniel, D. (2010), "E-books or textbooks: students prefer textbooks", Computers and Education, Vol. 55 No. 3, pp. 945-948, doi: 10.1016/j.compedu.2010.04.005.

\section{Corresponding author}

Kim Roberts can be contacted at: kim.roberts@athens.edu

For instructions on how to order reprints of this article, please visit our website: www.emeraldgrouppublishing.com/licensing/reprints.htm Or contact us for further details: permissions@emeraldinsight.com 